\title{
Study on SBS Modified Asphalt Waterproof Binding Course
}

\author{
Chenguang Wan \\ Highway School \\ Chang'an University \\ Xi'an,China \\ e-mail: 610510686@qq.com \\ Aiqin Shen \\ Highway School \\ Chang' an University \\ Xi'an,China \\ e-mail: 672121381@qq.com
}

\author{
Li Fan \\ Highway School \\ Chang'an University \\ Xi'an,China \\ e-mail: 573836575@qq.com \\ Yuan Zhang \\ Highway School \\ Chang'an University \\ Xi'an,China \\ e-mail: 474034095@qq.com
}

\begin{abstract}
According to the early disease of bridge deck pavement caused by waterproof-binding course, pavement performance of commen waterproof-binding course was was studied. First, determining the optimum spraying volume of modified asphalt under different treatments of leveling course through the pavement multi-function shear apparatus and laboratory pull-out test instrument, and the three kinds of surface treatment methods aer picking treatment,notch groove treatment and galling treatment, among which the optimum spraying volume of modified asphalt of picking and notch groove treatments are $1.4-1.6 \mathrm{~kg} / \mathrm{m}^{2}$, and the galling treatment is $1.6-1.8 \mathrm{~kg} / \mathrm{m}^{2}$. Through analyzing the test results, the shear strength and and bond strength of galling treatment is much higher than the shear strength of picking and notch groove treatments; Temperature and water are inportant factors of shear strength and bond strength of waterproof-binding course, and with the temperature increasing, the shear strength and bond strength reduced significantly; On the other hand, the results proved that ensuring waterproofness of bridge deck pavement is very important.
\end{abstract}

Keywords-road engineering; waterproof-binding course; bridge deck pavements; shear test; pull-out test.

\section{INTRODUCTION}

The typical structure of the cement concrete bridge deck pavement is composed of cement concrete leveling layer, waterproof and cohesive layer and the asphalt pavement laye [1]. In recent years,a lot of new bridge deck pavement structure appeared early diseases, disintegration and water damage is particularly serious with waterproof and cohesive layer local failure caused by time[1-7].As a bridge deck pavement structure of the "nexus" , Waterproof andcohesive layer plays a crucial role in the transmission of the force and displacement between the asphalt pavement layer and cement concrete leveling layer[8].Waterproof and cohesive layer is not only can bonding the concrete leveling layer and the asphalt pavement layer as a whole, but also provide an isolation moisture barrier, prevent rain or salt solution because of the deicing salt from the bridge deck,greatly improve the durability of bridge deck pavement[7-12].Therefore, this paper selected the SBS modified asphalt Synchronous Crushed stone seal coat as waterproof layer,In the different leveling layer surface treatment measures, different SBS modified asphalt spraying volume and different temperature on the shear performance, anti pull property is studied, providing a theoretical basis for design and construction of bridge deck waterproof bonding layer.

\section{THE DESIGN OF THE EXPERIMENTAL SCHEME}

\section{A. Materials and technical index}

Modified asphalt synchronous gravel waterproof and cohesive layer and the asphalt pavement layer are made of 4.5\% Shell SBS modified asphalt.Technical indicators in Table 1 are shown.

\begin{tabular}{|c|c|c|c|}
\hline \multicolumn{2}{|c|}{ Testing item } & $\begin{array}{c}\text { F SBS MODIFIED } \\
\text { Technical } \\
\text { requirements }\end{array}$ & $\begin{array}{l}\text { HALT } \\
\text { Testing } \\
\text { results }\end{array}$ \\
\hline \multicolumn{2}{|c|}{ Penetration $\left(25^{\circ} \mathrm{C}, 100 \mathrm{~g}, 5 \mathrm{~s}\right) /(0.1 \mathrm{~mm})$} & $60-80$ & 63 \\
\hline \multicolumn{2}{|c|}{ Penetration index } & $\geq-0.4$ & 0.02 \\
\hline \multicolumn{2}{|c|}{$\operatorname{Ductility}\left(5 \mathrm{~cm} / \mathrm{min}, 5^{\circ} \mathrm{C}\right) /(\mathrm{cm})$} & $\geq 30$ & 41 \\
\hline \multicolumn{2}{|c|}{ Softening point $(\mathrm{R} \& \mathrm{~B}) /\left({ }^{\circ} \mathrm{C}\right)$} & $\geq 55$ & 92.0 \\
\hline \multicolumn{2}{|c|}{ Kinematic viscosity $\left(135^{\circ} \mathrm{C}\right) /\left(\mathrm{Pa}^{\circ} \mathrm{s}\right)$} & $\leq 3$ & 1.843 \\
\hline \multicolumn{2}{|c|}{ Solubility/(\%) } & $\geq 99$ & 99.65 \\
\hline \multicolumn{2}{|c|}{ Elastic recovery $\left(25^{\circ} \mathrm{C}\right) /(\%)$} & $\geq 65$ & 94.2 \\
\hline \multirow{3}{*}{$\begin{array}{l}\text { Rotate asphalt filmy } \\
\text { heating operational } \\
\text { test }\left(163^{\circ} \mathrm{C}, 75 \mathrm{~min}\right)\end{array}$} & Mass loss $/(\%)$ & $\leq \pm 1.0$ & 0.053 \\
\hline & $\begin{array}{l}\text { Penetration } \\
\text { ratio/(\%) }\end{array}$ & $\geq 60$ & 78.4 \\
\hline & $\begin{array}{l}\text { Ductility }(5 \\
\left.{ }^{\circ} \mathrm{C}\right) /(\mathrm{cm})\end{array}$ & $\geq 20$ & 28 \\
\hline
\end{tabular}

Modified asphalt synchronous gravel waterproof and cohesive layer of stone are made of the size of $4.75 \mathrm{~mm}$ $9.5 \mathrm{~mm}$ grade limestone.Technical indicators in Table 2 are shown.

TABLE II. TECHNICAL INDEX OF AGGREGATE

\begin{tabular}{|l|l|l|}
\hline \multicolumn{1}{|c|}{ Testing item } & \multicolumn{1}{c|}{$\begin{array}{c}\text { Technical } \\
\text { requirements }\end{array}$} & \multicolumn{1}{c|}{$\begin{array}{c}\text { Testing } \\
\text { results }\end{array}$} \\
\hline Crushing value index/(\%) & $\leq 10$ & 9.0 \\
\hline Acicular content/(\%) & $\leq 7$ & 3.7 \\
\hline $\begin{array}{l}\text { Los Angeles abrasion } \\
\text { value/(\%) }\end{array}$ & $\leq 15$ & 7.6 \\
\hline Mud content/(\%) & $\leq 0.5$ & 0.3 \\
\hline Adhesion/(Level) & $\leq 4$ & 3 \\
\hline
\end{tabular}


B. Concrete leveling layer and asphalt pavement mixture ratio

The leveling layer using C40 concrete, asphalt pavement layer in direct contact with the AC-20C type asphalt concrete, the mixture ratio are shown in Table 3 and Table 4.

TABLE III. C40 CONCRETE MIX PROPORTION

\begin{tabular}{|c|c|c|c|c|c|c|c|}
\hline \multirow{2}{*}{$\begin{array}{c}\text { Water cement } \\
\text { ratio }\end{array}$} & \multirow{2}{*}{$\begin{array}{l}\text { Sand } \\
\text { ratio }\end{array}$} & \multicolumn{6}{|c|}{ Material dosage $/\left(\mathrm{kg} / \mathrm{m}^{3}\right)$} \\
\hline & & $\begin{array}{l}\text { Cement } \\
\text { content }\end{array}$ & $\begin{array}{l}\text { Fly ash } \\
\text { content }\end{array}$ & $\begin{array}{c}\text { Water } \\
\text { content }\end{array}$ & $\begin{array}{c}\text { Fine aggregate } \\
\text { content }\end{array}$ & $\begin{array}{c}\text { Coarse aggregate } \\
\text { content }\end{array}$ & $\begin{array}{c}\text { Water reducing agent } \\
\text { content }\end{array}$ \\
\hline 0.33 & 0.35 & 360 & 40 & 132 & 671 & 1247 & 4 \\
\hline
\end{tabular}

TABLE IV. MiXTURE PROPORTIONING OF AC-20

\begin{tabular}{|c|c|c|c|c|c|c|}
\hline \multirow{2}{*}{$\begin{array}{l}\text { Asphalt- } \\
\text { aggregate } \\
\text { ratio/(\%) }\end{array}$} & \multicolumn{6}{|c|}{ Proportion of every stall aggregate/(\%) } \\
\hline & $\begin{array}{l}\text { Mineral } \\
\text { powder }\end{array}$ & $\begin{array}{c}0- \\
2.36 \\
\end{array}$ & $\begin{array}{c}2.36- \\
4.75 \\
\end{array}$ & $\begin{array}{c}4.75- \\
9.5\end{array}$ & $\begin{array}{c}9.5- \\
19 \\
\end{array}$ & $\begin{array}{l}19- \\
26.5\end{array}$ \\
\hline 4.1 & 3 & 26 & 5 & 22 & 32 & 12 \\
\hline
\end{tabular}

\section{Experimental equipment}

\section{1) Pavement multi-function shear apparatus}

Deck paving interlaminar shear capacity is a key index to evaluate the performance of the bridge deck pavement, shear capacity shortage is one of the main reasons causing the diseases of the bridge deck pavement.Pavement multifunction shear apparatus can test the speed setting pavement structure shear strength, and then evaluate the interlayer treatment measures and performance of waterproof and cohesive layer quality.

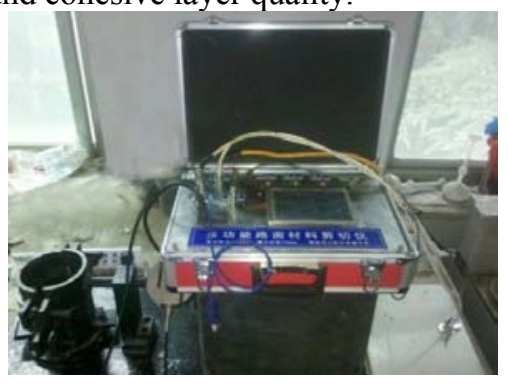

Figure 1. Pavement shear apparatus

\section{2) Laboratory pull-out test instrument}

Pullout test instrument used to determine the bond strength of the adhesive layer and the concrete leveling layer between the lower asphalt pavement.The analysis thinks, the bonding strength have great influence on fatigue performance of the bridge deck pavement[5]. Therefore, the waterproof and adhesive layer bond strength is also an important index of bridge deck pavement performance.

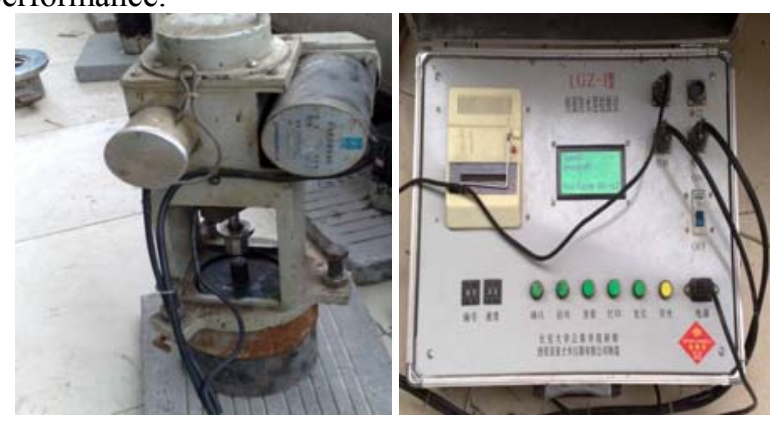

Figure 2. Drawing tester

\section{Specimen molding}

Shear test and pullout test specimens were used of high $100 \mathrm{~mm}, 100 \mathrm{~mm}$ diameter cylinder specimen. To simulate the real structure of bridge deck pavement rutting, first using the $300 \mathrm{~mm} * 300 \mathrm{~mm} * 100 \mathrm{~mm}$ test mode, using the cement concrete and the SBS modified asphalt synchronous gravel waterproof and cohesive layer and asphalt pavement layer structure to forming specimens.For the simulation of the construction site, respectively on the concrete surface galling, grooving and galling treatment, as shown in Fig.3.

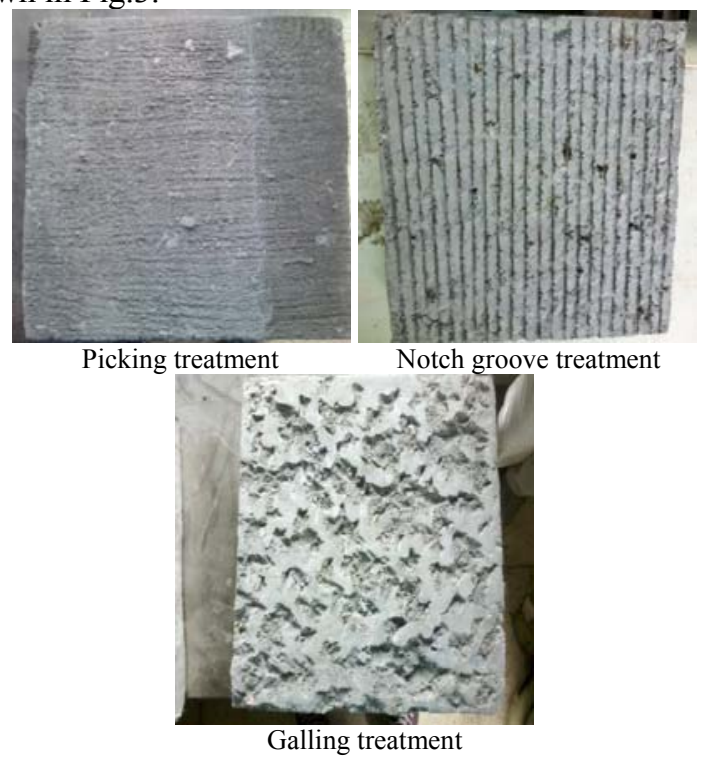

Figure 3. Surface treatments of concrete

Then paving waterproof adhesive layer, asphalt pavement, finally rolling with wheel rolling forming machine.Stay plate specimen cooling, with core drilling machine for drilling $100 \mathrm{~mm}$ diameter cylinder specimen. It should be ensured the concrete surface coverage rate at around $80 \%$, spreading quantity is about $6 \mathrm{~kg} / \mathrm{m}^{2}$ when bestrewing the detritus.Forming specimens as shown in Fig.4.

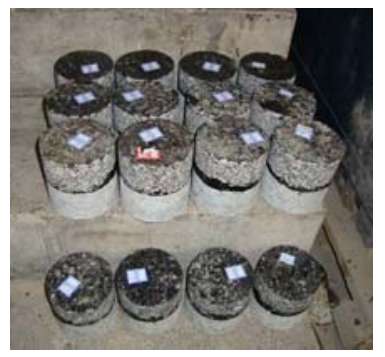

Figure 4. Molded speciments 


\section{ANALYSIS OF EXPERIMENTAL RESULTS}

A. Effect of asphalt dosage and temperature on the shear performance

SBS modified asphalt content are $1.2 \mathrm{Kg} / \mathrm{m}^{2}, 1.4 \mathrm{Kg} / \mathrm{m}^{2}$, $1.6 \mathrm{Kg} / \mathrm{m}^{2}, 1.8 \mathrm{Kg} / \mathrm{m}^{2}$, for picking and groove processing measures, texture direction should be perpendicular to the shear direction, direct shear rate $10 \mathrm{~mm} / \mathrm{min}$, were performed in different condition of $0^{\circ} \mathrm{C}, 20^{\circ} \mathrm{C}, 40^{\circ} \mathrm{C}$ and $40^{\circ} \mathrm{C}$ water bath respectively. Test results are shown in Table 5.

TABLE V. TEST RESULTS OF SHEAR STRENGTH/(MPA)

\begin{tabular}{|c|c|c|c|c|c|c|}
\hline \multirow{2}{*}{ Treatments } & \multirow{2}{*}{ Temperature $/\left({ }^{\circ} \mathrm{C}\right)$} & \multicolumn{5}{|c|}{ Spraying dosage of SBS modified asphalt $/\left(\mathrm{Kg} / \mathrm{m}^{2}\right)$} \\
\hline & & 1.2 & 1.4 & 1.6 & 1.8 & 2.0 \\
\hline \multirow{4}{*}{ Picking treatment } & 0 & 2.016 & 2.143 & 2.127 & 2.051 & 1.947 \\
\hline & 20 & 0.471 & 0.549 & 0.576 & 0.442 & 0.405 \\
\hline & 40 & 0.209 & 0.218 & 0.221 & 0.204 & 0.196 \\
\hline & 40(Water bath) & 0.096 & 0.117 & 0.110 & 0.101 & 0.093 \\
\hline \multirow{4}{*}{ Notch groove treatment } & 0 & 1.982 & 2.106 & 2.114 & 2.043 & 1.901 \\
\hline & 20 & 0.449 & 0.531 & 0.540 & 0.434 & 0.389 \\
\hline & 40 & 0.197 & 0.223 & 0.219 & 0.206 & 0.185 \\
\hline & 40(Water bath) & 0.078 & 0.106 & 0.101 & 0.088 & 0.073 \\
\hline \multirow{4}{*}{ Galling treatment } & 0 & 2.254 & 2.337 & 2.469 & 2.458 & 2.306 \\
\hline & 20 & 0.543 & 0.626 & 0.667 & 0.701 & 0.583 \\
\hline & 40 & 0.226 & 0.254 & 0.312 & 0.330 & 0.231 \\
\hline & 40(Water bath) & 0.112 & 0.126 & 0.154 & 0.147 & 0.106 \\
\hline
\end{tabular}

The test results show, the same treatment measures, the concrete surface under the same temperature, with the increase of SBS modified asphalt spraying volume, shear strength was first increased and then decreased against a combination structure. When the modified asphalt spraying volume is $1.4 \sim 1.6 \mathrm{Kg} / \mathrm{m}^{2}$, the picking and groove in various temperature conditions reach the maximum shear strength.Galling treatment measures under different temperature conditions, when modified asphalt spraying volume is $1.6 \sim 1.8 \mathrm{Kg} / \mathrm{m}^{2}$, the maximum shear strength. Description modified asphalt has an optimal sprinkle quantity, there exists an optimal thickness of asphalt film. When the asphalt film is too thin, not enough to climb to the height of waterproof and cohesive layer bestrew detritus, cause the bond strength of modified asphalt and gravel shortage, structural shear strength of low. When the spray volume too much, asphalt film is too thick, will form the free asphalt, rich reservoir formed in the interface, also cause the decrease in shear strength.For the three kinds of concrete surface treatment measures, at the same temperature and the same modified asphalt spraying volume conditions, picking and groove processing measures for structural shear strength was significantly lower than the galling treatment measures under the structure of shear strength, increases in the range of $15 \%$ $50 \%$, and the higher the temperature increases the amplitude of the more obvious,Under the condition of $40^{\circ} \mathrm{C}$, chiseling structure optimum asphalt spraying volume lower shear strength than the picking and groove respectively increase $49 \%$ and $48 \%$.Investigate its reason, mainly lies in the depth of the concrete surface structure under different treatments, and at one point the scope, the higher the shear strength of anti structure in greater depth the structure.

Sprinkle the amount of cloth in the same conditions, the same asphalt surface treatment measures, with the increase of temperature, shear strength significantly reduced.To reach the minimum in $40^{\circ} \mathrm{C}$ water bath condition, in order to galling treatment measures, asphalt spraying volume for the case of $1.8 \mathrm{Kg} / \mathrm{m}^{2}, 87 \%$ and $94 \%$ respectively to reduce the shear strength of structure anti shear strength is $0^{\circ} \mathrm{C}$ resistant structure of $40^{\circ} \mathrm{C}$ and $40^{\circ} \mathrm{C}$ water bath conditions.It shows that the temperature and moisture have significantly influence on SBS modified asphalt waterproof bonding layer shear strength. Therefore, in high temperature season, it is particularly necessary for proper control of bridge traffic overload vehicle.

\section{B. Effect of asphalt dosage and temperature on the bonding properties}

Similar to shear test, pullout test of SBS modified asphalt content also are $1.2 \mathrm{Kg} / \mathrm{m}^{2}, 1.4 \mathrm{Kg} / \mathrm{m}^{2}, 1.6 \mathrm{Kg} / \mathrm{m}^{2}$, $1.8 \mathrm{Kg} / \mathrm{m}^{2}, 10 \mathrm{~mm} / \mathrm{min}$ drawing rate, performed at different condition of $0^{\circ} \mathrm{C}, 20^{\circ} \mathrm{C}, 40^{\circ} \mathrm{C}$ and $40^{\circ} \mathrm{C}$ water bath respectively. Test results are shown in Table 6.

TABLE VI. TEST RESULTS OF PULL-OUT STRENGTH/(MPA)

\begin{tabular}{|c|c|c|c|c|c|c|}
\hline \multirow{2}{*}{ Treatments } & \multirow{2}{*}{ Temperature/( $\left.{ }^{\circ} \mathrm{C}\right)$} & \multicolumn{5}{|c|}{ Spraying dosage of SBS modified asphalt $/\left(\mathrm{Kg} / \mathrm{m}^{2}\right)$} \\
\hline & & 1.2 & 1.4 & 1.6 & 1.8 & 2.0 \\
\hline \multirow{4}{*}{ Picking treatment } & 0 & 1.791 & 1.834 & 1.926 & 1.718 & 1.617 \\
\hline & 20 & 0.474 & 0.667 & 0.578 & 0.406 & 0.383 \\
\hline & 40 & 0.221 & 0.346 & 0.301 & 0.216 & 0.173 \\
\hline & 40(Water bath) & 0.123 & 0.148 & 0.139 & 0.128 & 0.116 \\
\hline \multirow{4}{*}{ Notch groove treatment } & 0 & 1.762 & 1.947 & 1.877 & 1.820 & 1.701 \\
\hline & 20 & 0.429 & 0.574 & 0.631 & 0.529 & 0.460 \\
\hline & 40 & 0.214 & 0.291 & 0.334 & 0.225 & 0.190 \\
\hline & 40(Water bath) & 0.096 & 0.133 & 0.129 & 0.117 & 0.101 \\
\hline \multirow{4}{*}{ Galling treatment } & 0 & 1.672 & 1.815 & 1.932 & 1.824 & 1.706 \\
\hline & 20 & 0.441 & 0.594 & 0.619 & 0.533 & 0.446 \\
\hline & 40 & 0.206 & 0.275 & 0.328 & 0.251 & 0.206 \\
\hline & 40(Water bath) & 0.091 & 0.127 & 0.133 & 0.141 & 0.107 \\
\hline
\end{tabular}


The pullout test results have similar rules with shear test, pullout test and shear test shows that there is a good correlation.Under the same surface treatment measures and under the same temperature, the structure of bond strength also increases with modified asphalt spraying volume and increases at first and then decreases, and the different measures of modified asphalt under the optimal sprinkle quantity and shear test are basically consistent, picking and groove is $1.4 \sim 1.6 \mathrm{Kg} / \mathrm{m}^{2}$, galling for $1.6 \sim 1.8 \mathrm{Kg} / \mathrm{m}^{2}$.

Sprinkle the amount of cloth in the same conditions, the same asphalt surface treatment measures, with the increase of temperature, the structure of bond strength also decreased significantly, To reach the minimum in $40^{\circ} \mathrm{C}$ water bath condition, in the case that galling treatment measures, asphalt spraying volume of $1.8 \mathrm{Kg} / \mathrm{m}^{2}, 86 \%$ and $92 \%$ respectively to reduce the shear strength of structure anti shear strength in the $0^{\circ} \mathrm{C}$ resistant structure in the $40^{\circ} \mathrm{C}$ and $40^{\circ} \mathrm{C}$ water bath conditions.It shows that the temperature and moisture have significantly influwnce on SBS modified asphalt waterproof adhesive layer bond strength, slightly lower than the shear strength.

Unlike the shear test is, at the same temperature and the same modified asphalt spraying volume condition, the bond strength of different surface treatment measures of no significant difference, basically the same, This shows that the structure depth has little effect on the waterproof adhesive layer bond strength.

\section{CONCLUSION}

i) Comprehensive shear test and pullout test results, when the leveling layer surface to picking and groove measures, recommend the best modified asphalt spraying volume is $1.4 \sim 1.6 \mathrm{Kg} / \mathrm{m}^{2}$. When the leveling layer surface roughening measures taken, recommend the best modified asphalt spraying volume is $1.6 \sim 1.8 \mathrm{Kg} / \mathrm{m}^{2}$.

ii) For shear test, at the same temperature and the same modified asphalt spraying volume conditions, galling treatment measures under the structure of shear strength was significantly higher than that of picking and groove processing measures, increases in the range of $15 \%$ $50 \%$. The pullout test, at the same temperature and the same modified asphalt spraying volume conditions, and there is no significant difference in the structure of bond strength with the three kinds of treatment measures. iii) The significant effect of shear strength and bond strength of anti temperature and water on the waterproof adhesive layer, with the increase of temperature, shear strength and bond strength were significantly reduced structure, reaching the lowest at $40^{\circ} \mathrm{C}$ water bath condition.

\section{REFERENCES}

[1] Zang Jicheng,Pan Zhenghua,Luo Jun,Wang Ping. Effect of Overloading and the Leveling Layer Thickness on Deck Pavement Stress of Continuous Rigid Frame Bridge [J].JOURNAL OF CHOUGQING JIAOTONG UNIVERSITY: NATURAL SCIENCE,2013,32(6):1137-1140.

[2] SUTANTO M H. Assessment of bond between asphalt layers [D]. Nottingham:University of Nottingham, 2009

[3] Wang Deqiang. Hydrodynamic behavior \& Meterial Optimization Research of Bridge Deck Pavement in Moist Heat Areas [D]. Xi'an:Chang'an University,2011.

[4] Huang Xiaoming.Research status summary of asphalt pavement technology on cement concrete bridge deck [J]. Journal of Traffic and Transportation Engineering, 2014,14(1):1-10.

[5] British Board of Agrément. Guidelines document for the assessment and certification of waterproofing systems for use on concrete decks of highway bridges[R]. Watford British Board of Agrément, 2005.

[6] Xu Ouming,Han Sen,Yu Jingtao.Effect of interlayer interface on structural performance of concrete bridge deck pavement [J].Journal of Chang'an University:Natural Science Edition, 2009,29(5):17-20.

[7] Yang Yusheng,Li Zhenxia,Wang Xuancang,Wang Rideng,Gao Zhiwei.Road performance of synchronous crushed stone waterproof binding course of bridge pavement $[\mathrm{J}]$. Journal of Chang' an University:Natural Science Edition, 2009,29(6):19-23.

[8] Cai Yanxia. Study on Composite Bridge Deck Waterproof Adhesive Layer for Humid and Rainy Area [D]. Xi'an:Chang'an University,2011.

[9] Gao Xuechi,Huang Xiaoming,Wang Songgen.Research on Waterproof and Cohesive layer for Long Span Prestressed Concrete Bridge Deck [J].Journal of Highway and Transportation Research and Development, 2005,22(8):70-73.

[10] YU X. C. ZHENG C.C. Neutral plane analysis of bonded twolayered slab on Winkler foundation [J]. Engineering Mechanics,2007,24(9),65-71.

[11] S.Timoshenko,J.Gere. MECHANIGS OF MATERIALS [M].California:Van Nostrand Reinbold Company,1972:169-172.

[12] GUAN Yong-sheng,HAN Chao,LI Ming-jun et al. Performance of Modified Epoxy Resin Waterproof Adhesive Layer on Cement Concrete Bridge Surface [J]. JOURNAL OF BUILDING MATERIALS, 2013,16(5):894-897. 